\title{
Zhitong Jiangu decoction mitigates osteoarthritis in rabbits via regulation of NF-KB signaling pathway
}

\author{
Li Xiaodong, Su Xinping*, Tan Xuyi, Luo Haien, He Canyu, Huang Gang, Zhang \\ Daowei, Zhu Kejian \\ Department of Orthopedics, Affiliated Hospital of Hunan Academy of Traditional Chinese Medicine, Changsha 410006, China
}

*For correspondence: Email: suxinping111@163.com; Tel: +86-13974848894

Sent for review: 26 November 2020

Revised accepted: 20 March 2021

\begin{abstract}
Purpose: To investigate the effect of Zhitong Jiangu decoction (ZJD) on osteoarthritis rabbits, and the mechanism of action involved.

Methods: Chondrocytes were obtained from the knees of osteoarthritic rabbits. These chondrocytes were randomly assigned to 7 groups: sham, 5, 10 and $20 \%$ normal serum groups; $5 \%$ ZJD, $10 \%$ ZJD and $20 \%$ ZJD groups. The gross and histopathological features of the rabbit cartilage were examined by microscopy. Each group was treated with a different concentration of rabbit normal serum or rabbit drug-containing serum. The protective effect of different concentrations of ZJD on the cells were determined. Cell proliferation and concentrations of IL-1 and MMP-3 were determined using cell counting kit (CCK) 8 and enzyme-linked immunosorbent assay (ELISA), respectively. The mRNA and protein expressions of inhibitor of nuclear factor-KB kinase $\alpha(I K K-\alpha)$ and nuclear factor kappa $B$ p65 (NF- $\kappa B$ p65) were determined by quantitative reverse transcription polymerase chain reaction (qRT$P C R)$ and immunoblotting, as appropriate.

Results: Gross and histopathological examinations of rabbit cartilage showed that osteoarthritis was successfully established in rabbit knee joint. Cell proliferation significantly and time- and concentrationdependently increased in drug-containing serum groups, relative to sham and normal serum-containing groups. However, expressions of NF-KB p65, IL-1, MMP-3 and IKK- $\alpha$ were markedly and time- and concentration-dependently reduced in drug-containing serum groups, relative to sham and normal serum-containing groups $(p<0.05)$.

Conclusion: These results indicate that ZJD mitigates osteoarthritis in rabbits via regulation of NF-KB signaling pathway. Thus, it can potentially be developed for the management of osteoarthritis.
\end{abstract}

Keywords: Chondrocytes, MMP-3, NF- $\kappa B$, Osteoarthritis, Zhitong Jiangu decoction

\begin{abstract}
This is an Open Access article that uses a fund-ing model which does not charge readers or their institutions for access and distributed under the terms of the Creative Commons Attribution License (http://creativecommons.org/licenses/by/4.0) and the Budapest Open Access Initiative (http://www.budapestopenaccessinitiative.org/read), which permit unrestricted use, distribution, and reproduction in any medium, provided the original work is properly credited.
\end{abstract}

Tropical Journal of Pharmaceutical Research is indexed by Science Citation Index (SciSearch), Scopus, International Pharmaceutical Abstract, Chemical Abstracts, Embase, Index Copernicus, EBSCO, African Index Medicus, JournalSeek, Journal Citation Reports/Science Edition, Directory of Open Access Journals (DOAJ), African Journal Online, Bioline International, Open-J-Gate and Pharmacy Abstracts

\section{INTRODUCTION}

Osteoarthritis, a chronic degenerative osteoarthrosis, is the main cause of disability in the elderly. It mostly affects the knee. Joint damage, inflammation, age, obesity, joint mechanics and heredity are risk factors for osteoarthritis [1]. The disease is characterized by degradation of articular cartilage, synovial inflammation, callus formation, as well as 
changes in articulating surfaces of bone and subchondral bone [2]. Therefore, a major strategy for the treatment of osteoarthritis is to stop or delay the degeneration of articular cartilage.

Zhitong Jiangu decoction (ZJD), a preparation used in Traditional Chinese Medicine (TCM), has been reported to be effective against osteoarthritis $[3,4]$. It inhibited synovial hyperplasia in a rabbit model of osteoarthritis [5]. Zhitong Jiangu decoction (ZJD) has been reported to increase the thickness of noncalcified cartilage, slow cartilage degeneration and improve joint function $[5,6]$. Moreover, it has been speculated that the preparation confers protection on chondrocytes via inhibition of inflammation and mRNA expressions of IKK- $\alpha$, NF-kB, MMP-1 and tumor necrosis factor $\alpha$ (TNF- $\alpha$ ) [7-9]. At present, the precise molecular mechanism underlying the effect of ZJD remains largely unknown. The present research was aimed at studying the influence of ZJD on osteoarthritic rabbits, and the mechanism involved.

\section{MATERIALS AND METHODS}

\section{Materials}

Fetal bovine serum (FBS) was product of Gibco. Diaminobenzidine (DAB) and two-step kit were purchased from Beijing Zhongshan Jinqiao Biotechnology Co. Ltd. Cell counting kit 8 (CCK8), Tris buffer and ELISA kits were bought from Sigma-Aldrich Ltd. Safranin O staining kit was obtained from Wellbio. TRIzol was product of Invitrogen. UltraSYBR mixture was bought from Beijing Kangwei Century Biotechnology Co. Ltd. White rabbit IKK- $\alpha$ and NF-KB-p65 mRNA primers were products of Shanghai Shenggong Bioengineering Technology Service Co. Ltd. Horse-radish peroxidase (HRP) goat anti-mouse IgG and HRP goat anti-rabbit IgG were purchased from Proteintech, while $\beta$-actin was bought from PeproTech. Microplate reader was product of Bio-Tek.

\section{Experimental rabbits}

Healthy New Zealand white male rabbits $(n=15)$ weighing $1.8-2.2 \mathrm{~kg}$ (mean weight $=2.0 \pm 0.2$ $\mathrm{kg}$ ) were obtained from the Animal Laboratory of Hunan Academy of TCM. The rabbits were housed in metal cages under standard conditions and allowed ad libitum access to feed and water. They were exposed to 12-h light/12-h dark cycle, and maintained at an average temperature of 22 $\pm 1{ }^{\circ} \mathrm{C}$ and $40-50 \%$ humidity. The rabbits were acclimatized to the laboratory conditions for 10 days prior to commencement of study. Study permission was received from the Animal Ethical Committee of The Affiliated Hospital of Hunan Academy of TCM, Changsha, China (approval no. 2018-0035). The study procedures were implemented in adherence to international guidelines [10].

\section{Experimental design}

Ten rabbits were numbered according to weight and randomly divided into two groups: ZJDcontaining serum group $(n=5)$ and blank control group $(n=5)$. Based on the formula of equivalent dose conversion for different animals [11], the dose of ZJD for the rabbits was calculated as $4.48 \mathrm{~g} / \mathrm{kg}$ body weight. The rabbits in the serum group were daily given intragastric administration of twice the equivalent dose, i.e., $8.96 \mathrm{~g} / \mathrm{kg}$ administered as $10 \mathrm{~mL} / \mathrm{kg} /$ day (the concentration of raw medicine containing ZJD was 0.896 $\mathrm{g} / \mathrm{mL}$ ). The blank control group was intragastrically administered an equivalent dose of normal saline $(10 \mathrm{ml} / \mathrm{kg} /$ day $)$, once a day for 7 days. One hour after intragastric administration on the $8^{\text {th }}$ day, $10 \%$ chloral hydrate was used for intraperitoneal anesthesia at a dose of $3.5 \mathrm{ml} / \mathrm{kg}$. Sera were derived from abdominal aorta blood containing the drug ZJD, and from normal rabbits (normal sera). These were inactivated in a constant temperature water bath at $56^{\circ} \mathrm{C}$ for 30 min, and kept refrigerated at $-20^{\circ} \mathrm{C}$ for later use. The serum samples were filtered and sterilized when needed.

\section{Establishment of rabbit model of osteoarthritis}

The remaining five rabbits were used to make rabbit model of osteoarthritis by injection of $4 \%$ papain into the knee joint, once every 3 days, in a total of 3 injections [12].

\section{Gross examination of rabbit knee joint}

Two weeks after establishment of rabbit model of osteoarthritis, the rabbits were euthanized via induction of air embolism. The knee joint of each rabbit was excised and the cartilage of femoral condyle and tibial plateau were macroscopically examined.

\section{Histopathological examination}

Histological examination of distal femoral cartilage was performed using $H$ \& $E$ staining, and safranin $O$ cartilage staining. Histopathological changes were assessed based on the degree of inflammatory cell infiltration, damage, underlying bone destruction and 
articular cartilage damage. The extent of cartilage damage was also determined using Mankin score [13].

\section{Isolation and culture of chondrocytes}

Chondrocytes were isolated via enzymatic digestion of bone tissue. The cartilage of each rabbit was excised under sterile conditions, cut into bits and crushed to a volume $<0.3 \mathrm{~mm}^{3}$. Then, $2 \mathrm{~mL}$ of $0.25 \%$ trypsin was added for digestion, and the mixture was shaken vigorously on a shaking incubator at $37^{\circ} \mathrm{C}$ for $20 \mathrm{~min}$. Then, $2 \mathrm{~mL}$ of $0.02 \%$ type II collagenase was added to the digest in Ham's F-12 medium and maintained for $24 \mathrm{~h}$ at $37^{\circ} \mathrm{C}$ in an atmosphere of $5 \% \mathrm{CO}_{2}$ and $95 \%$ oxygen. The cell suspension was sieved using a cell strainer to get rid of debris. The filtrate was subjected to centrifugation at 15,000 rpm for $7 \mathrm{~min}$ and the sediment was rinsed in DMEM. The cells were inoculated in a culture flask at a density of $4 \times$ $10^{4}$ cells $/ \mathrm{mL}$ and maintained in DMEM containing $10 \%$ FBS and $1 \%$ streptomycin/penicillin at 37 ${ }^{\circ} \mathrm{C}$ in an incubator with $5 \% \mathrm{CO}_{2}$ and $95 \%$ oxygen. The culture medium was changed every 2 to 3 days, and cell growth was observed under a microscope every $24 \mathrm{~h}$. Knee articular chondrocytes were identified with collagen immunofluorescence staining $[14,15]$. The thirdgeneration chondrocytes were employed in this research.

\section{Cell grouping}

When the chondrocytes attained $80 \%$ confluency, they were randomly assigned to 7 groups: sham, 5, 10 and $20 \%$ normal serum groups; $5 \%$ ZJD, $10 \%$ ZJD and $20 \%$ ZJD groups. Cells in sham group were treated with $0.5 \%$ volume fraction of FBS, while those in 3 normal serum groups were treated with 5,10 or $20 \%$ volume fractions of normal rabbit serum. Moreover, 5, 10 or $20 \%$ volume fraction of serum containing ZJD was added to the 3 ZJD groups, as appropriate.

\section{Determination of proliferative potential}

This was done using CCK- 8 kit. The cells were inoculated in 96-well plates $\left(2 \times 10^{4} / \mathrm{mL}\right)$, and maintained at $37{ }^{\circ} \mathrm{C}$ for $24 \mathrm{~h}$ in a medium of $5 \%$ $\mathrm{CO}_{2}$ and $95 \%$ oxygen, followed by addition of CCK-8. The mixture was cultured for $4 \mathrm{~h}$, after which OD was read at $450 \mathrm{~nm}$. The assay was done in triplicate at $24 \mathrm{~h}$ intervals.

\section{Determination of levels of IL-1 and MMP-3 in cell suspension}

The cells were rinsed in PBS and lysed with icecold RIPA buffer containing protease blocker. The resultant lysate was spun at 15, $000 \mathrm{rpm}$ for $15 \mathrm{~min}$ at $4{ }^{\circ} \mathrm{C}$, and the supernatant was subjected to assay of $\mathrm{IL}-1$ and MMP-3 using ELISA.

\section{Quantitative RT-PCR}

Total RNA extraction from cells of each group was done with TRIzol RNA extraction reagent. The RNA was reverse-transcribed to cDNA, followed by qRT-PCR. The relative mRNA expression levels of IKK- $\alpha$ and NF-KB p65 were calculated using $2^{-\Delta \Delta C t}$ method, with GAPDH as internal standard. Table 1 shows the nucleotide sequences of primers employed.

\section{Determination of protein expression levels}

Protein expressions of IKK- $\alpha$ and NF-KB p65 in chondrocytes were measured using Western blotting.

\section{Statistical analysis}

Results are presented as mean \pm SD. Groups were compared using Tukey, Welch and GamesHowell tests, where applicable. Statistical analysis was performed with SPSS version 24 . Values of $p<0.05$ were taken as indicative of statistically significant differences.

Table 1: Sequences of primers used for PCR

\begin{tabular}{llll}
\hline Gene & Primer & Sequence & Length \\
\hline GAPDH & Sense & 5'- TGGAATCCACTGGCGTCTTCAC -3' & 168bp \\
& Anti-sense & 5'- AGGATGCGTTGCTGACAATCTTGA -3' & \\
IKKa & Sense & 5'-ACAAAGAGCAGCAATGTTAAGCC -3' & $149 \mathrm{bp}$ \\
& Anti-sense & $5^{\prime}$ - ACAAAGAGCAGCAATGTTAAGCC -3' & \\
NFKB-p65 & Sense & $5^{\prime}$ - ATGCCAATGCCCTCTTCGACT -3' & $164 \mathrm{bp}$ \\
& Anti-sense & $5^{\prime}$ - CGTGACTTCCAGCAGATCCCT -3' & \\
\hline
\end{tabular}




\section{RESULTS}

\section{Results of gross examination of rabbit knee joint}

The articular cartilage surface of normal rabbit appeared light pink. Cartilage defect, joint effusion and swelling of synovial membrane were absent. However, the cartilage surface of osteoarthritic rabbits was white, with articular cavity effusion and synovial swelling. The rough surface was characterized by reduced brightness and visible marginal cartilage defect (Figure1).
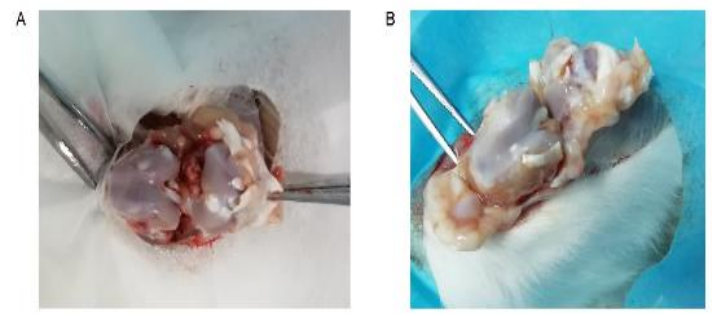

Figure 1: Gross morphology of rabbit knee joint. (A): Normal knee joint; and (B): knee joint of osteoarthritis rabbit

\section{Histopathological features of cartilage of rabbit}

Hematoxylin and eosin ( $\mathrm{H}$ \& $\mathrm{E}$ ) staining of rabbit distal femoral cartilage revealed diffused increase in the number of chondrocytes as well as uneven distribution of chondrocytes in each layer (Figure $2 \mathrm{~A}$ and B). Similarly, Safranin O cartilage staining revealed a slight decrease in staining of the matrix and irregular cracks on the joint surface (Figure 2C and D). The modified Mankin's score was 3.
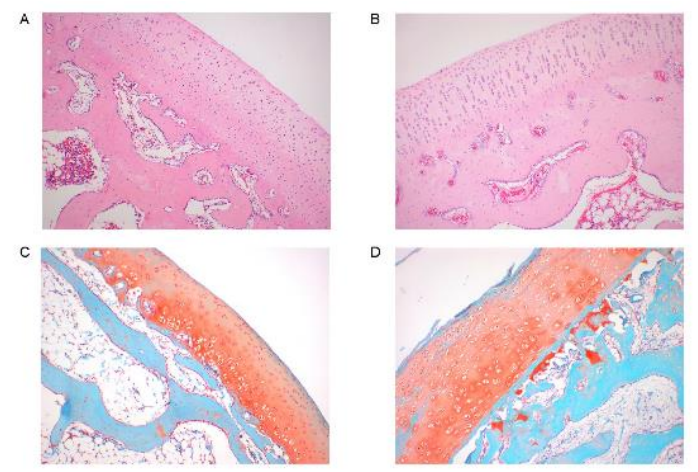

Figure 2: Histopathological features of cartilage of rabbits. (A): $H$ \& $E$ staining of cartilage of normal rabbit; (B): $H$ \& $E$ staining of cartilage of osteoarthritic rabbit; (C): Safranin O staining of cartilage of normal rabbit; and (D): Safranin O staining of cartilage of osteoarthritic rabbit

\section{Morphological characteristics of isolated chondrocytes}

Chondrocytes isolated from cartilage of osteoarthritis rabbit adhered gradually to the wall of the culture flask within $24 \mathrm{~h}$ of separation. Most of the primary chondrocytes remained spherically suspended in the culture medium with strong refractive properties (Figure $3 \mathrm{~A}$ ). After 72 $\mathrm{h}$ of culture, primary chondrocytes were completely adherent to the wall, with most of their nuclei appearing round or oval. The cells were polygonal, triangular, or short spindleshaped. There were protrusions between cells, and colony formation units were observed (Figure $3 \mathrm{~B}$ and $\mathrm{C}$ ). After 9 days, monolayer cells were formed, which spread to cover the bottom of the culture flask. The nuclei were larger, and the cytoplasm was uniform and closely arranged. The entire monolayer cells formed a "paving stone"-like structure (Figure $3 \mathrm{D}$ ). After the first passage, the adherent time of chondrocytes was significantly reduced, but cell proliferation was markedly enhanced. Most of the cells were triangular and spindle shaped, with only a few appearing polygonal (Figure $3 \mathrm{E}$ ). The observed morphological changes were characteristic of chondrocytes.
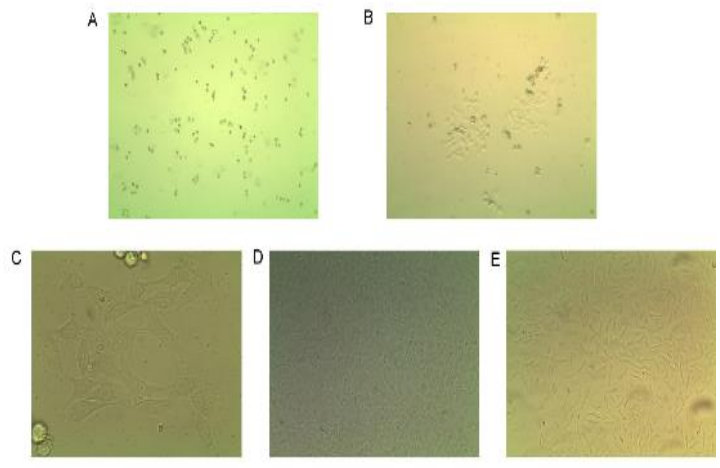

Figure 3: Morphological characteristics of isolated chondrocytes. (A): Appearance of primary cells after $24 \mathrm{~h}$ ( $\times 100)$; (B \& C): Appearance of primary cells after 72 h (b: × 100; c: × 400); (D): "Paving stone"-like structure of isolated chondrocytes ( $\times 100)$; and $(E)$ : First generation of chondrocytes $(\times 100)$

\section{Type II collagen immunocytochemical staining}

As shown in Figure $4 \mathrm{~A}$ and $\mathrm{B}$, the nuclei of isolated chondrocytes appeared brown or brownish-yellow. The results of type II collagen immunofluorescence staining showed that type II collagen was mainly distributed in the cytoplasm and membrane of isolated chondrocytes (Figure $4 \mathrm{C}-\mathrm{E})$. 


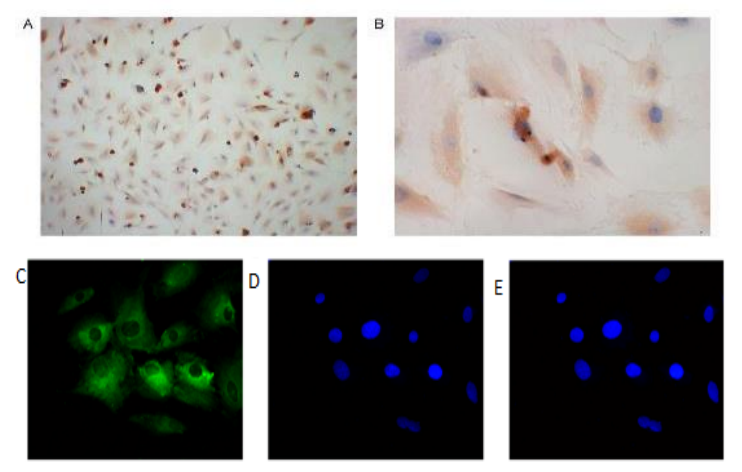

Figure 4: Immunohistochemical features of chondrocytes. (A and B): Type II collagen (a: $\times 100$; b: $\times 400$ ); (C): Type II collagen positive signal pattern; (D): staining of cell nucleus; and (E): Type II collagen immunofluorescence staining $(\times 400)$

\section{Proliferation of chondrocytes}

The proliferation of chondrocytes was significantly lower in sham group than in normal serum-containing groups $(p<0.05)$. Cell proliferation was significantly and time- and concentration-dependently increased in drugcontaining serum groups, relative to sham and normal serum containing groups $(p<0.05$; Figure 6 and Figure 7).

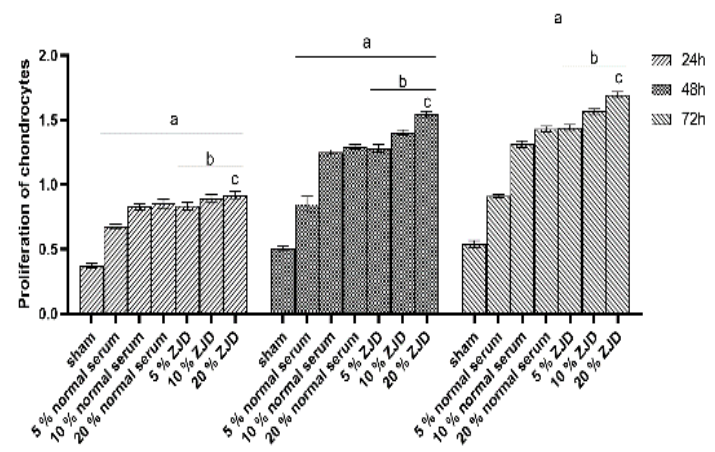

Figure 6: Proliferation of chondrocytes at 24, 48 and $72 \mathrm{~h}$ of culture. ${ }^{\mathrm{a} P}<0.05$, vs sham group; ${ }^{\mathrm{b}} p<0.05$, vs normal serum-containing groups; ${ }^{c} p<0.05$, compared with 5 and $10 \%$ ZJD groups

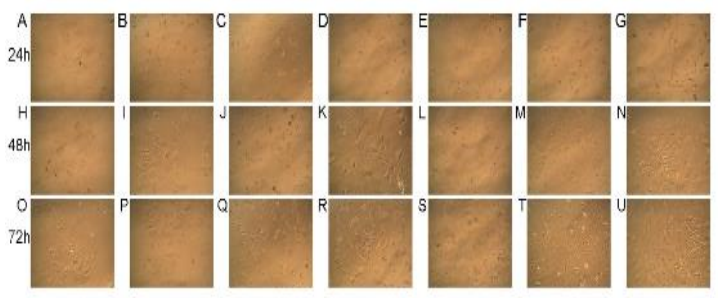

Figure 7: Microscopic observation of chondrocytes in each group after drug intervention $(\times 100)$. A, H and $\mathbf{O}$ : Sham group; B, I and P: $5 \%$ normal serum group; C, J and Q: $10 \%$ normal serum group; D, K and R: 20
$\%$ normal serum group; $\mathbf{E}, \mathbf{L}$ and S: $5 \%$ ZJD drug serum group; $\mathbf{F}, \mathbf{M}$ and $\mathbf{T}: 10 \%$ ZJD drug serum group; G, N and U: 20 \% ZJD drug serum group

\section{Levels of expression of IL-1 and MMP-3}

As presented in Figure 8 and Figure 9, the levels of expression of IL-1 and MMP-3 were markedly higher in sham group than in normal serumcontaining groups $(p<0.05)$. Interleukin 1 (IL-1) and MMP-3 expression levels were significantly and time- and concentration-dependently reduced in drug-containing serum groups, relative to sham and normal serum-containing groups $(p<0.05)$.

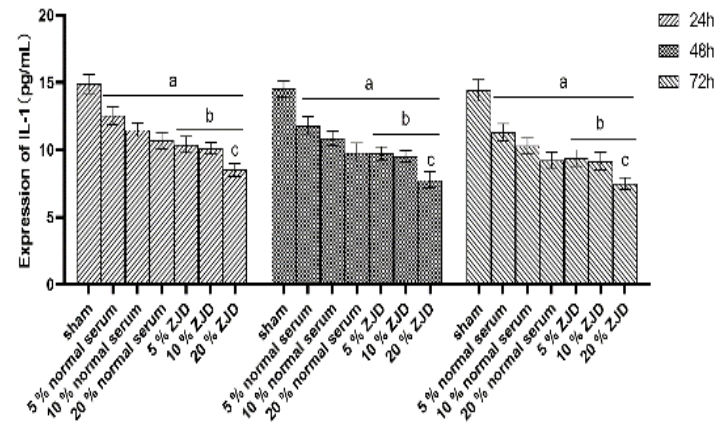

Figure 8: Levels of expression of IL-1 at 24,48 and 72 h of culture. ${ }^{a} P<0.05$, vs sham group; ${ }^{b} p<0.05$, vs normal serum-containing groups; ${ }^{c} p<0.05$, compared with 5 and $10 \%$ ZJD groups

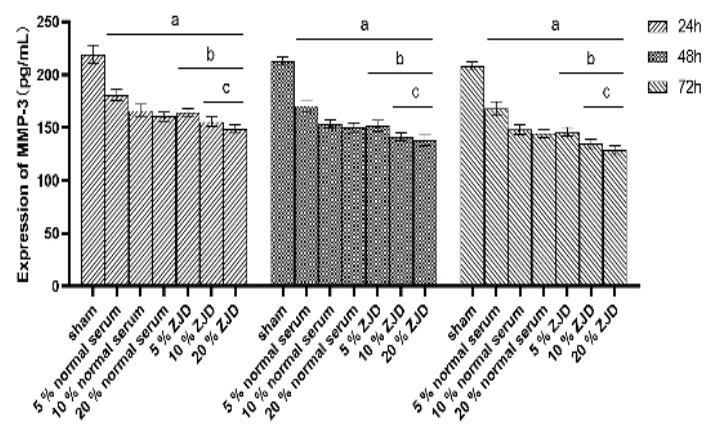

Figure 9: Expression of MMP-3 at 24, 48 and $72 \mathrm{~h}$ culture. ${ }^{a} P<0.05$, vs sham group; ${ }^{b} p<0.05$, vs normal serum-containing groups; ${ }^{c} p<0.05$, compared with 5 and $10 \% Z J D$ groups

\section{mRNA and protein levels of NF-KB p65 and IKK- $\alpha$}

Markedly higher mRNA and protein expressions of NF-KB p65 and IKK- $\alpha$ were seen in sham group than in normal serum-containing groups $(p$ $<0.05$ ). In drug-containing serum groups, the mRNA and protein concentrations of these factors were significantly and time- and 
concentration-dependently downregulated, relative to sham and normal serum-containing groups ( $p<0.05$; Figure 10 and Figure 11).
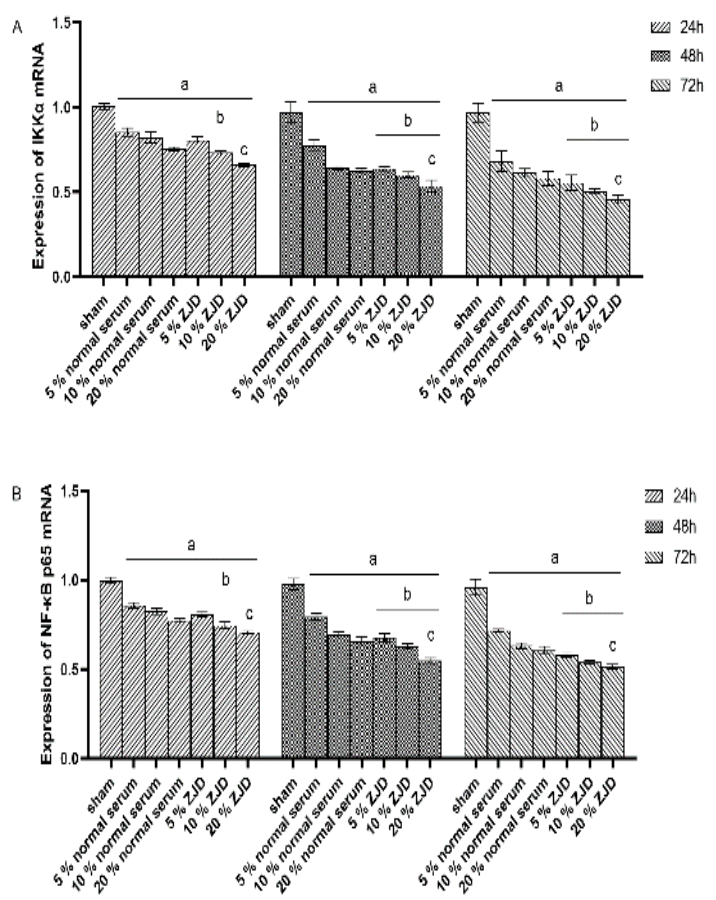

Figure 10: mRNA levels of NF-KB p65 and IKK- $\alpha$. mRNA expressions of IKK- $\alpha$ (A) and NF-KB p65 (B). ${ }^{a} P<0.05$, compared with sham group; ${ }^{b} p<0.05$, vs normal serum-containing groups; ${ }^{c} p<0.05$, compared with 5 and $10 \%$ ZJD groups

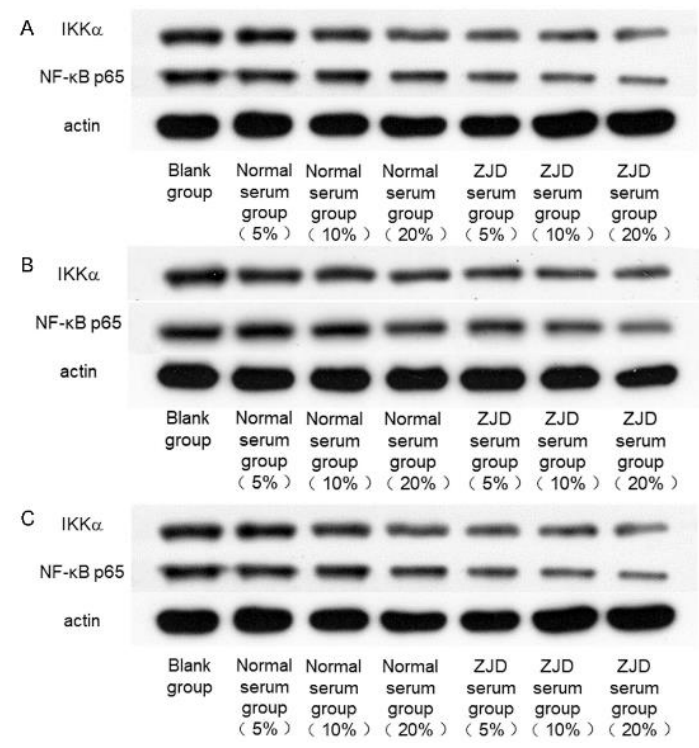

Figure 11: Effect of treatments on apoptosis. NF-kB p65 and IKK- $\alpha$ protein levels after $24 \mathrm{~h}(\mathrm{~A})$; after $48 \mathrm{~h}$ (B), and after $72 \mathrm{~h}$ of culture (C)
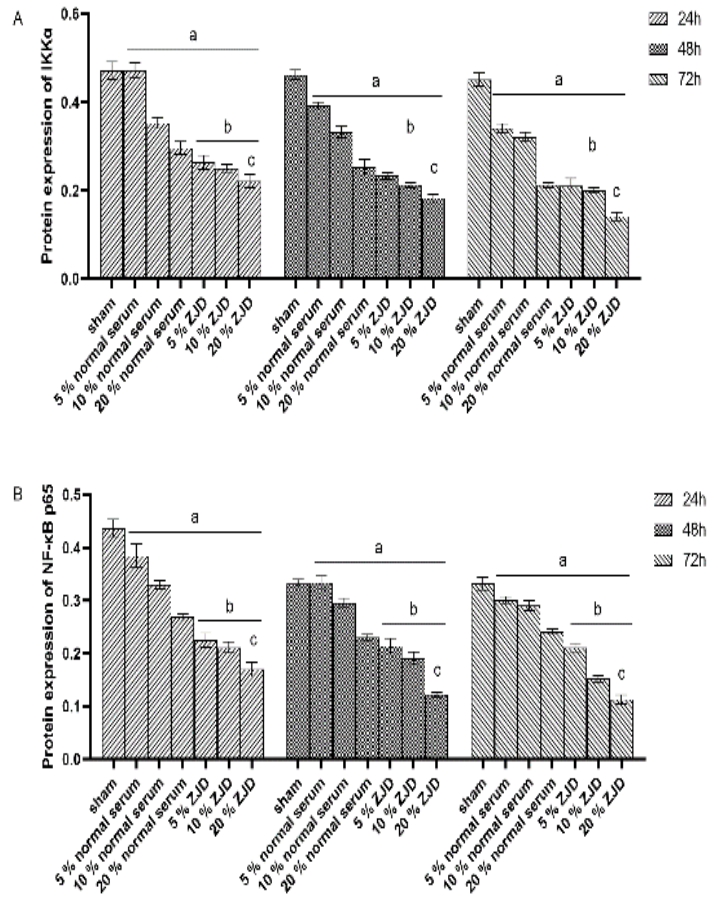

Figure 12: IKK- $\alpha$ and NF-KB p65 protein concentrations at 24,48 and $72 \mathrm{~h}$ of culture. (A): IKK$\alpha$ protein level; and $(B)$ : protein expression level of NF-kB-p65

\section{DISCUSSION}

Osteoarthritis, a degenerative disease of the bones and joints, occurs mainly in the knee joint, hip joint, spine and other parts of the body in middle-aged and the elderly people. It is mainly caused by pain and joint dysfunction. Pain of long duration induces local inflammation of joint soft tissue, thereby causing damage to cartilage [1]. Early osteoarthritis is characterized by painful joints, stiffness and hypertrophy. Several factors may be involved in etiology of knee osteoarthritis. The NF-kB signaling pathway which is implicated in aging and inflammation, is involved in the pathophysiological changes of osteoarthritis [16]. Activated NF-KB causes damage to the extracellular matrix, thereby setting in motion the pathological processes that culminate in osteoarthritis. The NF-KB signaling pathway regulates homeostasis of articular chondrocytes in various ways, and it has been reported to modulate apoptosis of chondrocytes via regulation of cell proliferation and apoptosisrelated genes [17]. In a previous study, NF-KB promoted apoptosis of chondrocytes via upregulation of the expressions of MMP-3, IL-1, IL-6 and TNF- $\alpha$ [18]. Moreover, MMP-3 and IL-1 are downstream products of the NF-KB signal pathway, which expressions are important in the 
etiology of osteoarthritis. The results of this study suggest that ZJD may protect chondrocytes via inhibition of NF-KB expression.

In Traditional Chinese Medicine (TCM), knee osteoarthritis is classified as bi syndrome, sinew bi and li jie feng. Zhitong Jiangu decoction (ZJD) is used in TCM to treat osteoarthritis $[3,4]$. It promotes blood circulation, relieves pain, removes invisible phlegm, dredges meridians, and strengthens the muscles and bones. The crude drug has been shown to inhibit synovial hyperplasia in rabbit model of knee osteoarthritis. A study reported that it increased the thickness of non-calcified cartilage, slowed cartilage degeneration, and improved joint function [4]. Downregulated expressions of MMP-1 and TNFa have been demonstrated to inhibit inflammatory reactions in osteoarthritis rabbits [3,5-9].

In this study, after the successful establishment of knee osteoarthritis, different volume fractions of ZJD-containing serum were used for treatment. The results suggest that ZJD may confer protection on chondrocytes and promote their proliferation.

\section{CONCLUSION}

These findings suggest that ZJD mitigated osteoarthritis in rabbits via regulation of the NF$\mathrm{KB}$ signaling pathway. The results provide supportive experimental evidence for the use of ZJD in the treatment of knee osteoarthritis in TCM.

\section{DECLARATIONS}

\section{Acknowledgement}

This work was funded by the National Natural Science Foundation of China (no. 81603482) and Hunan Scientific Research Program of TCM (no. 201908).

\section{Conflict of interest}

No conflict of interest is associated with this work.

\section{Contribution of authors}

We declare that this work was done by the authors named in this article, and all liabilities pertaining to claims relating to the content of this article will be borne by them. Xiaodong Li, Xuyi Tan and Haien Luo conducted the literature search, performed the experiments and drafted the manuscript. Xinping Su and Kejian Zhu participated in the design and conduction of the experiment. Canyu He, Gang Huang and Daowei Zhang performed the statistical analysis and assisted in writing of the manuscript. All authors read and approved the final manuscript.

\section{Data availability statement}

The raw data generated in this study are available on request.

\section{Open Access}

This is an Open Access article that uses a funding model which does not charge readers or their institutions for access and distributed under the terms of the Creative Commons Attribution License (http://creativecommons.org/licenses/by/ 4.0) and the Budapest Open Access Initiative (http://www.budapestopenaccessinitiative.org/rea d), which permit unrestricted use, distribution, and reproduction in any medium, provided the original work is properly credited.

\section{REFERENCES}

1. Goldring MB, Goldring SR. Osteoarthritis. J Cell Physiol. 2007; 213 (3): 626 - 634.

2. Gu YJ, Ge P, Mu Y, Lu JH, Zheng F, Sun XG. Clinical and laboratory characteristics of patients having amyloidogenic transthyretin deposition in osteoarthritic knee joints. J Zhejiang Univ Sci B. 2014; 15 (1): 92 - 99.

3. Li XD, Su XP, Tan XY, Luo HEN, He CY, Huang G, Zhang DW. Clinical Effect of Zhitong Jiangu Decoction in Treatment of Knee Synovitis with the Syndrome of Intermingled Phlegm and Blood Stasis. J Hunan Univ Chin Med. 2018; 38 (8): 908 -912.

4. Zhang K, Qiu XZH, Zhu KJ. Clinical research of Zhitong JianGu Decoction on 60 patients with Osteoarthritis. Lishizhen Med Mater Med Res. 2019; 30 (2): 383 - 385.

5. Su XP, Zhu KJ, Tan XY. Effects of Zhitong Jiangu Decoction on Synovial and Cartilage Repair in Rabbit. J Hunan Univ Chin Med. 2016; 36 (4): 11 - 14.

6. Tan XY, SU XP, Luo HEN, Zhang K, He CY, Huang G, Ding ZHX. Effects of Zhitongjiangu decoction on microstructure of synovial membrane in knee osteoarthritis. Lishizhen Med Mater Med Res. 2018; 29 (8): $1793-1795$.

7. Su XP, Zhu KJ, Tan $X Y$, He CY, Huang G, Zhang $K$. Expression of IKKa and NF-KB mRNA for Zhitong jiangu Recipe on Cartilage of knee osteoarthritis. Chin J Tradit Med Traumatol Orthop. 2017; 25 (10): 1 - 5.

8. Su XP, Zhu KJ, Tan XY, He CY, Huang G, Zhang K, Ding $Z H X$. Effect of zhitong jiangu prescription on MMP-1 of cartilage in rabbit knee osteoarthritis and correlation analysis with MRI grading. Lishizhen Med Mater Med Res. 2017; 28 (4): 812 - 815.

Trop J Pharm Res, April 2021; 20(4): 747 
9. Su XP, Zhu KJ, Tan XY, Ding ZHX, He CY, Huang G, Zhang $K$. Effect of Zhitong Jiangu Decoction on Cartilage TNF- $\alpha$ Expression in Knee Osteoarthritis Rabbits and Its Correlation with Articular Cartilage Mankin 's Score. Guiding J Tradit Chin Med Pharm. 2017; 23 (14): $23-26+30$.

10. National Research Council (US) Institute for Laboratory Animal Research. Guide for the Care and Use of Laboratory Animals. Washington (DC), National Academies Press (US), 1996.

11. Wei $W, W u$ XM, Li YJ. Experimental Methodology of Pharmacology, ed 4, revised. Beijing, People's medical publishing house Co. Ltd., 2010.

12. Tang HB, Li TT, Yang YJ, Chen BF, Ma RY, Yan HY, Li YS, Feng LJ. The Dynamic Change of Pathological Indicators in Papain-Induced Rat Osteoarthritis. J SouthCent Univ Natl, Nat Sci Ed. 2013; 32 (4): 41 - 45.

13. Zeng JH, Ma DJ, Peng LP, He SH, Yu T, Chen D. Establishment and identification of experimental rabbit knee osteoarthritis model. Chin J Clin Res. 2016; 29 (5): $679-682$.

14. Hu ZJ, Hu B, Tang DZH, Zhang YW, Wang SW, Wang YJ. Isolation, culture and morphological characteristics of rabbit articular cartilage cells. Chin J Tissue Eng Res. 2010; 14 (46): 8555 - 8558.

15. Liu XR, Zhang L, Gao W, Lu QY, Meng Y. Isolation, culture and identification of New Zealand rabbit articular cartilage cells. Int J Lab Med. 2012; 33 (19): 2307 $2308+2312$.

16. Marcu KB, Otero M, Olivotto E, Borzi RM, Goldring MB. NF-kappaB signaling: multiple angles to target OA. Curr Drug Targets. 2010; 11 (5): 599 - 613.

17. Saito T, Tanaka S. Molecular mechanisms underlying osteoarthritis development: Notch and NF-kB. Arthritis Res Ther. 2017; 19 (1): 94.

18. Liu $Y X$, Wang GD, Wang $X$, Zhang $Y L$, Zhang TL. Effects of TLR-2/NF-KB signaling pathway on the occurrence of degenerative knee osteoarthritis: an in vivo and in vitro study. Oncotarget. 2017; 8 (24): 38602 - 38617. 